\title{
Shared accommodation services are changing the hospitality market in cities
}

\author{
Pavla Burešová1, Katarína Mrkvová1, Branislav Dudić ${ }^{2^{*}}$ \\ ${ }^{1}$ College of Business and Hotel Management, Brno, Czech Republic \\ ${ }^{2}$ Comenius University, Faculty of Management, Bratislava, Slovakia, and University \\ Business Academy, Faculty of Economics and Engineering Management, Novi Sad, \\ Republic of Serbia
}

\begin{abstract}
This study is focused on changes in the accommodation services market affected by shared accommodation platforms. The housing services market in the Czech Republic is segmented complexly. Traditional types of accommodation including hotels, pensions and hostels are using digital platforms such as Trivago, Booking, TripAdvisor, etc. only to mediate offered short-term housing services. The offer of so-called shared accommodation has expanded considerably. One of the most widespread is a digital platform Airbnb acting as an accommodation service provider mediating private immovable properties as well as collective accommodation facilities.
\end{abstract}

Keywords: Airbnb, hotel, shared accommodation, hospitality market, cities, services JEL classification: L83, Z32

\section{Kolaborativne usluge smeštaja menjaju hotelijersko tržište u gradovima}

Sažetak: Ova studija je fokusirana na promene na tržištu usluga smeštaja na koje utiču kolaborativne platforme za izdavanje smeštaja. Tržište stambenih usluga u Češkoj Republici je veoma segmentirano. Tradicionalni tipovi smeštaja, koji uključuju hotele, pansione i hostele, koriste digitalne platforme kao što su Trivago, Booking, TripAdvisor i druge samo za posredovanje u ponudi kratkoročnih smeštajnih usluga. S druge strane, ponuda takozvanog kolaborativnog smeštaja znatno se proširila. Jedna od najrasprostranjenijih je digitalna platforma Airbnb koja pruža uslugu smeštaja, posredujući u izdavanju privatnih nekretnina, kao i kolektivnih smeštajnih objekata.

Ključne reči: Airbnb, hotel, kolaborativni smeštaj, hotelijerstvo, gradovi, usluge JEL klasifikacija: L83, Z32

\section{Introduction}

Accommodation services have evolved thanks to the hospitality of the clergy in monasteries since the 11th century. Besides monasteries, for a short-term stay it was also possible to use so-called hospices (hospitals), which took care of the sick, orphans and the elderly. In the 12th and 13th centuries along with the development of trade, there is a demand for new accommodation possibilities. Later on, in the 14th century, there are coaching inns being

* dudicbranko@yahoo.com 
formed providing meal services besides providing accommodation. The term 'hotel' has been used since the first half of the 19th century. A hotel provides short-term accommodation replacing the comfort of home. It is "a facility providing accommodation, meals and other services for travellers and paying guests.” A hotel is a place that offers accommodation to all categories of travellers in return for a fee. Depending on the category and technical equipment, a hotel also provides other services such as food, social-entertainment, relaxation, and conference services - in fact, all possible relevant services (Kř́ižek \& Neufus, 2011).

Nowadays, we can choose among small original boutique hotels, the striking architecture of design hotels, various concepts of large hotel chains, or independent accommodation facilities providing a variety of highest-quality services for different groups of customers. Around the world, different methodologies are being applied in order to promote service transparency. Since 2004, the methodology of The Official Uniform Classification of Accommodation Facilities has been used in the Czech Republic, which defines a hotel as: “... an accommodation facility with at least 10 guest rooms equipped so as to provide temporary accommodation and related services” (Hotelstars, 2018).

Traditional accommodation services are subject to various regulations set by laws, directives and other acts under applicable legislation. A separate Annex No. 4 to Government Regulation No. 278/2008 Coll. includes the list of contents of free trades by individual activities: "Providing the accommodation in all accommodation establishments (e.g., hotel, motel, camp, hostel) and in apartment buildings, family houses or family recreational buildings. In case of accommodation in apartment buildings, family houses or family recreational buildings with a capacity of up to 10 beds (including extra beds) serving breakfast for accommodated guests” (Accommodation Services, 2019).

These are Act No. 455/1991 Coll. on Trades Licensing (Trade Licensing Act), as amended by Act No. 513/1991 Coll., Commercial Code, replaced by Act No. 89/2012 Coll. Government Regulation No. 469/2000 Coll., determining the contents of individual trades, as amended. Government Regulation No. 491/2004 Coll., Government Regulation No. 100/2005 Coll. and Government Regulation No. 324/2006 Coll. Government Regulation No. 140/2000 Coll. establishing a list of fields of individual trades, as amended by Government Regulation No. 468/2000 Coll., Government Regulation No. 492/2004 Coll., as amended by Government Regulation No. 100/2005 Coll. and Government Regulation No. 324/2006 Coll.

Shared accommodation can be defined as a short-term rental of vacant real estate or its part to visitors for a certain fee or free of charge. Among the first organizations to provide shared accommodation was Servas International, established in 1949 as a community aimed at deepening and strengthening understanding, tolerance and peace. The key ideas of the organization were direct experience, which should help eliminate prejudice against foreign cultures, enabling learning, communication, and personal experience. One of the most outstanding companies focusing on house and apartment exchange is HomeExchange, which was established in 1992 and is operating worldwide based on annual membership contributions that allow members to exchange. The exchange itself is free of charge. Couchsurfing International Inc. was founded in 2004 following the principle of gaining experience of foreign culture as well as personal experience of shared accommodation. Couchsurfing is currently present in more than 200,000 cities with around 14 million people organizing more than 500,000 events (About Couchsurfing, 2018; Eckhardt \& Bardhi, 2018). Another accommodation provider is an American company HomeAway, offering more than a million real estate properties in 190 countries (About the Family, 2018).

In Europe, shared services are acting within the organization The European Holiday Home Association (EHHA, 2018). Since 2013, its members have been for example Airbnb, 
HomeAway, Interhome, TripAdvisor, VacationRentals, etc. (Eckhardt \& Bardhi, 2018; HomeExchange, 2018; Matofska, 2018).

Shared accommodation services are growing worldwide. The massively used platforms include Airbnb, which has gained many enthusiasts but also opponents over the course of ten years. Airbnb is a community platform that allows its users to offer, search and book unique accommodations all around the world via their PC, mobile phone or tablet. It can be an overnight stay in an apartment, a week stay in a castle or a longer stay in a villa at different price levels in more than 34,000 cities and 190 countries in the world. With its excellent customer service and a growing community of users, Airbnb offers people the easiest way to monetize their unused accommodation capacities as well as to offer these to millions of people from around the world (Airbnb, 2018; Joffrion, 2018).

By clicking on the link www.airbnb.com, one sees the option "Book unique homes and experiences" along with other icons offering homes, experiences and restaurants. In the upper right corner, navigation continues with the offer "Become a Host", where after pointing the cursor option "Earn up to 19719 Kč a month hosting in Brno" appears (Airbnb, 2018).

\section{Materials and methods}

During the study, we used the legislation applicable to accommodation facility providers. The research of the cited authors is focused on laws, regulations and decrees (legislation) as well as on the published articles cited according to valid standards. The secondary research uses data analysis, comparative, and statistical methods. The primary data were obtained by means of a questionnaire, and the data collection was performed in three stages from September 2018 to January 2019 on social networks. The answers of 480 respondents were used to assess the use of the Airbnb shared accommodation platform. According to the level of completed education, $43 \%$ of the respondents have completed secondary education, $51 \%$ higher education and 6\% did not indicate the level of their education. To evaluate results and comparisons, we used Excel tools and statistical methods. The purpose of the questionnaire was to find out the level of popularity of using Airbnb by domestic travellers as well as the opinions of the guests and hosts.

\section{Results and discussion}

So far, the legislation of the Czech Republic has not adopted any law encompassing shared services in relation to Airbnb or similar service providers. An accommodation service provider (hotels, etc.) is subject to the laws imposing the obligation to pay taxes and to conduct business in compliance with public regulations (Bajtler, 2019).

According to the analysis prepared for the Office of the Government of the Czech Republic by TACR (Technology Agency of the Czech Republic), the results of shared accommodation services in Prague achieve lower level than $20 \%$ of the services offered by "real" hosts. The remaining $80 \%$ can be considered as very close to usual business activities. According to this study, Airbnb no longer fulfills the function of attractive shared accommodation, but it is rather an organized business. The majority of accommodation capacities are provided by entities that usually offer a number of properties. For this type of providers, Airbnb represents quite an anonymous sphere (Analysis, 2019).

The original intention of shared accommodation to get to know and understand foreign cultures through personal experience and communication is unfortunately disappearing. In many cities, residents are noticing the negative effects associated with the offered services. 
These negative aspects include for instance loss of authenticity and atmosphere of the city, which results in the relocation of the original city dwellers who are leaving the city centers, so that their properties serve tourists only. As an example, we can mention the cities of Amsterdam and Berlin, where the entire neighborhoods have been adapted to visitors, which has consequently further contributed to even higher rental prices (Analysis, 2019).

According to Marvanová, local residents in Prague often complain about the behaviour of the accommodated guests, mostly including night-time noise disturbance and a mess in their houses. These aspects lead to the depopulation of the city center, which is not a positive phenomenon in the long term (Accommodation services, 2019).

Fialová and Dumbrovská from the Faculty of Science of Charles University in Prague report: “... the center of Prague has become a tourist ghetto ...", shops, services and restaurants are primarily focused on visitors affecting the quality of life of the original city dwellers. As an example, they take the Royal Route (Powder Tower, Charles Bridge, Prague Castle) with 349 tourist-oriented services in 2015 compared to 27 entities focusing exclusively on the residents (Tourism destroys city centers. They are depopulating, 2019).

Another factor influencing urban authenticity is gentrification, which has already penetrated into some parts of Prague (Airbnb, 2018). Gentrification is a way or a trend transforming poorer city areas into attractive locations. This brings about other changes, such as rising real estate and rental prices or expulsion of original city dwellers, who no longer have financial means to live in their original residences and thus have to move out to be replaced by other more powerful layers of the population (Mareš, 2006; Šubrt, 2008). After renovations, vacant houses and apartments are rented at several times greater prices. As an example, we can mention Jiřího z Poděbrad Square, where apartments are being rented for 50.000, 70.000 and sometimes 100.000 Czech crowns (Accommodation services, 2019).

Results from the questionnaire of domestic respondents (a convenience sample) including 480 people aged between 18 and 70, indicated that less than a quarter, only 24\% of the respondents had used Airbnb to rent at least one accommodation unit. About one per cent less said that they did not know the platform under review. $14 \%$ of the respondents said they were discouraged from creating a profile on Airbnb, and 19\% of the respondents indicated their distrust in the platform. A fifth of the respondents (20\%) prefer hotels. These results are quite surprising given the fact that almost $3 / 4$ of the respondents are booking their accommodation on the Internet. The remaining 19\% are using travel agencies, see Figure 1.

Figure 1: Accommodation reservation method

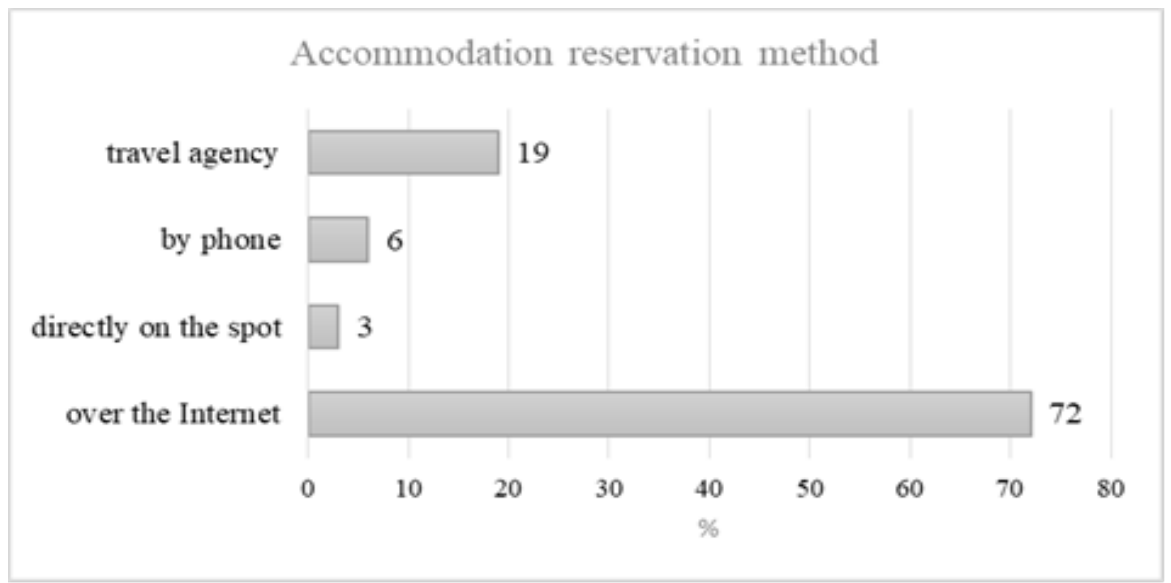

Source: Own elaboration with data from vsoh, 2018 
Considering the frequency of traveling using accommodation services, we may predict an increase in the number of guests using Airbnb. As for the question "How often do you travel on vacation using accommodation services?” $32 \%$ of the respondents answered that they spend their vacation using accommodation more than 3 times a year. 35\% of the respondents go on vacation once a year and $30 \%$ use accommodation services twice a year. Only $3 \%$ travel without using accommodation.

Figure 2: Frequency of traveling using accommodation services

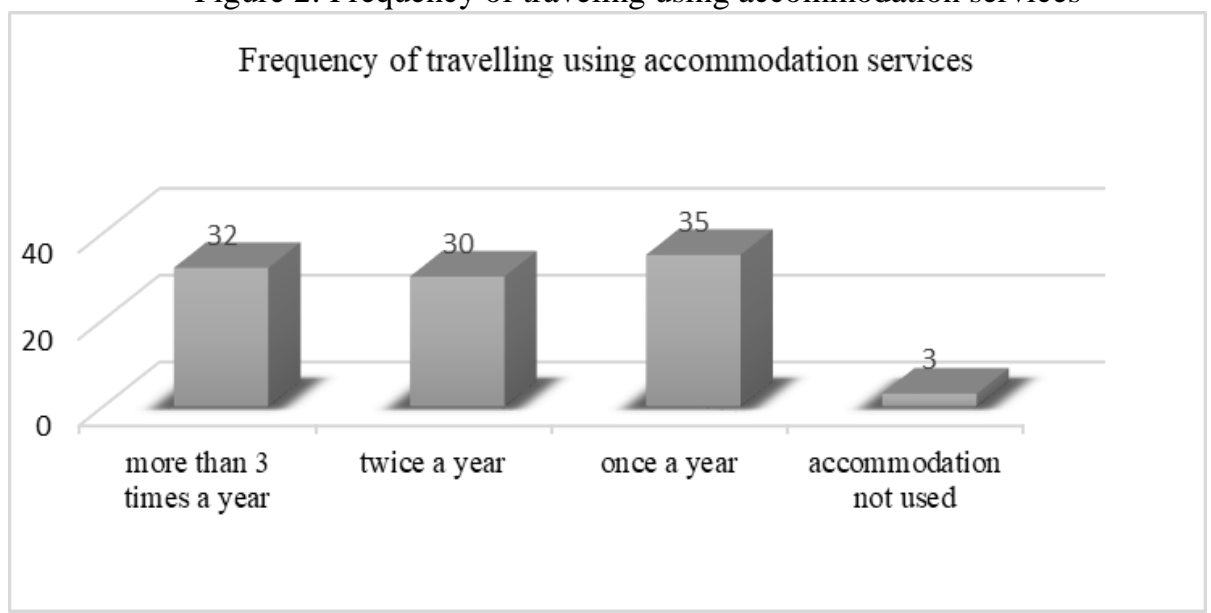

Source: Own elaboration with data from vsoh, 2018

Another question has revealed the data showing an increasing demand for accommodation related to a wide offer not only in the category of hotels but also Airbnb and similar platforms. The overnight accommodation bookings for about 1 week (5-7 nights) prevail (54\% of the respondents). Besides, $29 \%$ are travelers who use accommodation for over 14-21 days. $5 \%$ of the respondents mostly travel for several months and $12 \%$ use the accommodation for 2-3 nights, which is a long-term average from a statistical point of view. The questionnaire points out the extension of a stay using the accommodation, see Figure 3.

Figure 3: Length of stay using accommodation

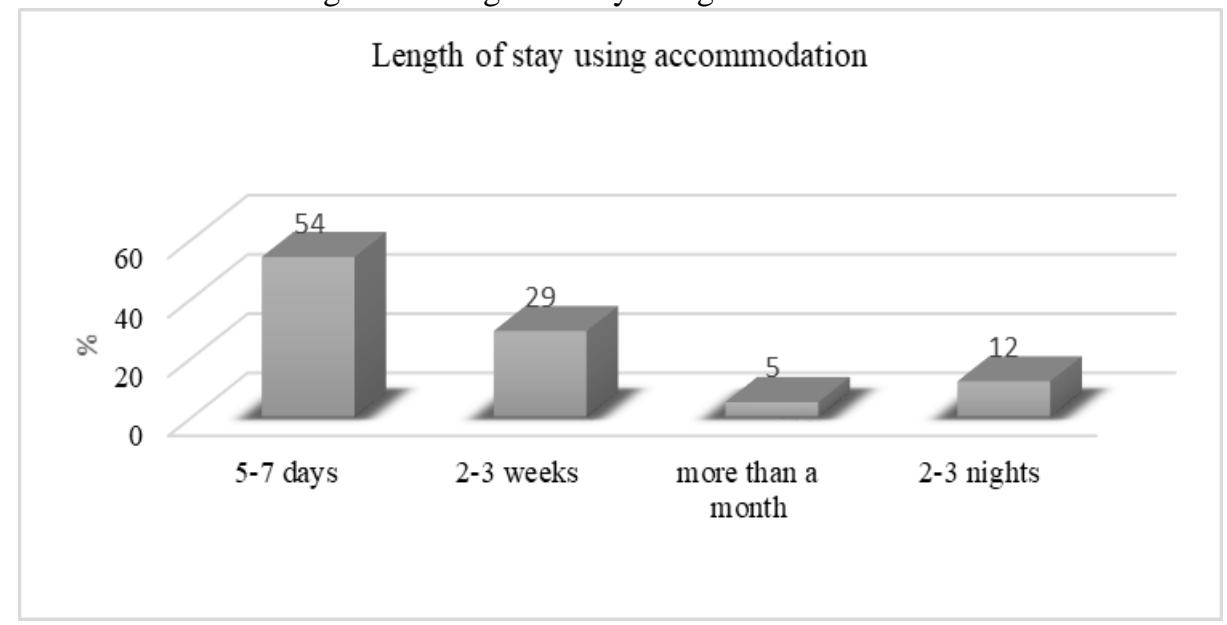

Source: Own elaboration with data from vsoh. 2018 
The American start-up platform Airbnb (currently estimated at $\$ 31$ billion) has its sympathizers as well as opponents. The former group appreciates the opportunity to rent a property and also the benefits such as more authentic travel options, improving the economic situation, etc. The latter group of opponents is criticizing Airbnb for not being compliant with laws, and furthermore for congestion of city centers by tourists, which as a result causes expulsion of the original city residents, who can no longer occupy their apartments (Airbnb, 2018).

\section{Conclusion}

Traditional accommodation services are operated based on their compliance with various regulations often associated with several restrictions. Originally, shared accommodation services were established with clear objectives, which have gradually disappeared in many cases. Nowadays, they are operating primarily as business activities that are no longer subject to applicable laws and regulations.

Representatives of major European cities have adopted certain opinions on shared services, thus have moved significantly further. Although Berlin reduced shared services sharply in the past, the regulations almost led to a ban. Nowadays, they have re-established the regulations and changed their position on Airbnb. In Amsterdam, they are restricting the number of nights per year a property can be rented out. An urbanist, Sito Veracruz, living in Amsterdam, is one of the strongest Airbnb opponents. In January 2019, together with his team, he launched his own project called FairBnB (Ptáček, 2019) which should be an ethical alternative to Airbnb. FairBnB wants to be transparent, and respectful of the laws. The key rule is that one host can only rent one property through this platform (Másson Mack, 2019).

Association HOTREC together with the member associations have long been calling for a distinction between professionals in the hotel industry and common shared services users in order to promote fair competition. The measures being introduced by Airbnb should provide greater clarity and transparency so as to ensure a fairer business environment for both consumers and the hotel sector. This will contribute to a more equitable tourism market in Europe, which will be beneficial especially for consumers (ㄴ́rek, 2019).

In the Czech Republic, an Amendment to the Local Fees Act is being prepared, which among others should establish charges associated with shared accommodation services. According to lawyer Jakub Štilce (Bajtler, 2019), the pending amendment will introduce a "certain fee per stay" which is currently applicable to commercial accommodation services only, especially hotels, however, will also apply to shared housing providers (Bajtler, 2019).

According to the president of the Czech Association of Hotels and Restaurants, Vaclav Stárek in an interview for iDnes.cz, small and medium-sized hotels are involved in the cooperation with Airbnb, as well. In 2016, small boutique hotels appeared on the Airbnb website, followed by other accommodation categories two years later. Airbnb offers hostels, holiday resorts or cottages, which represent a change in terms of extended services such as breakfast (Stárek, 2019). Václav Stárek also mentions a competing digital platform for Airbnb, which is Booking.com, offering much more secluded accommodations compared to hotel rooms (tárek, 2019).

Considering the economic, global, political and social changes in the society, it is hard to predict further development of accommodation services. Nevertheless, the progress in terms of the way of booking the accommodation (72\% of travellers are buying online over the Internet) is irreversible. These facts point to the ever-changing accommodation services market dynamics in the category of hotel services that will have to adapt to new directions, including shared accommodation platforms, such as Airbnb or FairBnB. 
Theoretical and practical benefits of the conducted study are mapping and comparing the legislative requirements for the operation of hotel accommodation services, which are still at a disadvantage compared to shared accommodation services. Also, identifying the positive and negative factors associated with shared accommodation (a positive factor - allows renting real estate, more authentic travel options, improving the economic situation. Finally, the results also show the changes in accommodation purchase behavior ( $72 \%$ of travelers buy online via the Internet).

\section{References}

1. About Couchsurfing. (2018). Retrieved October 6, 2018 from http://www.couchsurfing.com/about/about-us/

2. About the Family. (2018). Retrieved November 11, 2018 from https://www.homeaway.com/info/about-the-family

3. Airbnb dưvěra a bezpečnost - Tvoje bezpečnost je u nás na prvním mistě. Rekreačni pronájmy, domovy, zážitky a místa - Airbnb [Airbnb trust and safety - Your safety comes first. Vacation Rentals, Homes, Experiences \& Places in Airbnb]. (2018). Retrieved October 6, 2018 from https://www.airbnb.cz/trust

4. Analyza [Analysis]. (2018). Retrieved September 28, 2018 from https://www.vlada.cz/assets/urad-vlady/poskytovani-informaci/poskytnute-informace-na zadost/Priloha_4 Material_Analyza.pdf

5. Bajtler, M. (2019). Praha má pro regulaci Airbnb svázané ruce, tvrdí advokát Jakub Štilec [Prague has hands tied for Airbnb regulation, claims Jakub Štilec]. Retrieved June 1, 2019 from https://www.idnes.cz/praha/zpravy/praha-regulace-airbnb-mesto-masvazane-ruce-nemovitosti.A181227 447367_praha-zpravy_nuc

6. Eckhardt, G., \& Bardhi, F. (2018). The Sharing Economy Isn't About Sharing at All. Harvard Business Review - Ideas and Advice for Leaders. Retrieved October 6, 2018 from https://hbr.org/2015/01/the-sharing-economy-isnt-about-sharing-at-all

7. EHHA.eu - European Holiday Home Association. (2018). Retrieved October 6, 2018 from http://ehha.eu/about-us

8. HomeExchange About HomeExchange.com ${ }^{\mathrm{TM}}$, the World's \#1 Home Exchange Site (2018). Retrieved November 1, 2018 from https://www.homeexchange. com/en/about

9. Hotelstars. (2018). Retrieved October 10, 2018 from https://www.hotelstars.cz

10. Joffrion, E. (2018). Airbnb Celebrates Record Growth With 10 Million Guest Nights Booked. Press Release and News Wire Services. Retrieved October 6, 2018 from http://www.marketwired.com/press-release/airbnb-celebrates-record-growth-with10-million-guest-nights-booked-1670787.htm/

11. Křížek, F., \& Neufus, J. (2011). Moderní hotelový management [Modern hotel management]. Praha: Grada.

12. Mareš, P. (2006). Faktory sociálního vyloučení [Factors of social exclusion]. Praha: VÚPSV, Výzkumné centrum Brno.

13. Másson Mack, M. (2019). FairBnB is an ethical alternative to Airbnb, coming in 2019. Retrieved January 8, 2019 from https://thenextweb.com/eu/2018/12/06/fairbnb-is-anethical-alternative-to-airbnb-coming-in-2019/

14. Matofska, B. (2018). What is the Sharing Economy? Welcome to the discovery site for the Sharing Economy and founders of Global Sharing Week. Retrieved October 6, 2018 from http://www.thepeoplewhoshare.com/blog/what-is-the-sharing-economy/

15. Ptáček, M. (2019). Urbanista z Amsterdamu spouští FairBnB, etickou alternativu $k$ Airbnb | CzechCrunch - nejčtenějši magazín o startupech a technologiích [An urban planner from Amsterdam launches FairBnB, an ethical alternative to Airbnb | CzechCrunch - the most read magazine about startups and technologies]. Retrieved 
January 6, 2019 from https://www.czechcrunch.cz/2018/12/urbanista-z-amsterdamuspousti-fairbnb-etickou-alternativu-k-airbnb/

16. Rekreační pronájmy, domovy, zážitky a místa - Airbnb [Vacation Rentals, Homes, Experiences \& Places - Airbnb]. (2019). Retrieved January 5, 2019 from https://www.airbnb.cz/

17. Stárek, V. (2019). Asociace hoteli̊ a restauraci České republiky [Association of hotels and restaurants of the Czech Republic]. Retrieved January 8, 2019 from https://www.ahrcr.cz/novinky/hotrec-k-postoji-ek-vuci-airbnb/

18. Starý dělnický Žižkov mizí, jeho tvár̆ mění vysoké nájmy i Airbnb. Dokáže se ubránit gentrifikaci? [The old working-class Žižkov disappears, its face changing high rents and Airbnb. Can he resist gentrification?]. (2019) Retrieved January 6, 2019 from https://wave.rozhlas.cz/stary-delnicky-zizkov-mizi-jeho-tvar-meni-vysoke-najmy-iairbnb-dokaze-se-7706251

19. Šubrt, J. (2008). Soudobá sociologie [Contemporary Sociology]. Praha: Karolinum.

20. Turistika likviduje centra měst. Vylidn̆uji se [Tourism destroys city centers. They are depopulating]. (2019). Retrieved January 5, 2019 from https://www.tyden.cz/rubriky/byznys/cesko/turistika-likviduje-centra-mestvylidnuji-se456221.html?showTab=diskutovano

21. Ubytovací služby [Accommodation services]. (2019). Retrieved January 20, 2019 from https://www.businessinfo.cz/cs/clanky/ubytovaci-sluzby-12762.html 